NBER WORKING PAPER SERIES

\title{
OBSERVATIONS ON INTERNATIONAL LABOR STANDARDS AND TRADE
}

\author{
Alan B. Krueger \\ Working Paper 5632
NATIONAL BUREAU OF ECONOMIC RESEARCH 1050 Massachusetts Avenue
Cambridge, MA 02138
June 1996

I thank Varuni Dayaratna for excellent research assistance, and Richard Freeman, Gene Grossman, Larry Katz, Jorge Perez-Lopez, Boris Pleskovic, Andrew Samet and Ken Swinnerton for helpful discussions. This paper was prepared for the World Bank's Annual Bank Conference on Development Economics, Washington, D.C., April 25-26, 1996. The findings, interpretations, and conclusions expressed in this paper are entirely those of the author. They do not necessarily represent the views of the National Bureau of Economic Research, the World Bank, its Executive Directors, or the countries they represent. This paper is part of NBER's research program in Labor Studies.

(C) 1996 by Alan B. Krueger. All rights reserved. Short sections of text, not to exceed two paragraphs, may be quoted without explicit permission provided that full credit, including (C) notice, is given to the source. 
NBER Working Paper 5632

June 1996

\title{
OBSERVATIONS ON INTERNATIONAL \\ LABOR STANDARDS AND TRADE
}

\begin{abstract}
$\underline{\text { ABSTRACT }}$
This paper reviews the theoretical arguments for and against linking international labor standards to trade. Based on theory alone it is difficult to generalize about the effect of labor standards on efficiency and equity. Some economists have argued that international labor standards are merely disguised protectionism. An evaluation of determinants of support for legislation that would ban imports to the United States of goods made with child labor provides little support for the prevailing political economy view. In particular, members of Congress representing districts with relatively many unskilled workers, who are most likely to compete with child labor, are less likely to support a ban on imports made with child labor. Another finding is that the prevalence of child labor declines sharply with national income. Last, an analysis of compulsory schooling laws, which are often suggested as an alternative to prohibiting child labor, finds a tremendous amount of noncompliance in developing nations.
\end{abstract}

\author{
Alan B. Krueger \\ Woodrow Wilson School \\ Princeton University \\ Princeton, NJ 08544 \\ and NBER
}


As national economies have become more integrated, the issue of international coordination of labor standards has become more prominent. Opponents of labor standards argue that international pressure on foreign countries is an unnecessary and counterproductive interference in the workings of the free market. In this view pressure for international labor standards represents either disguised protectionism or misplaced compassion. Proponents of labor standards argue that a set of minimal labor standards is necessary to promote fair competition and to facilitate efficient operation of the labor market. In industrialized countries there has also been a growing undercurrent of resentment toward trade with countries with low labor costs, which threatens the viability of international trade agreements. In the United states, for example, this opposition has been galvanized by presidential candidate Pat Buchanan, but it also has been voiced by several union leaders and liberal politicians.

The core areas of labor standards typically include freedom of association, collective bargaining, prohibition of forced labor, elimination of exploitative child labor, and nondiscrimination. ${ }^{1}$ The International Labor Organization (ILO) has been the main institution concerned with international labor standards since its inception in 1919. The ILO establishes conventions that are binding only on the countries that ratify them. The ILO is not empowered to enforce compliance with ratified conventions; instead, it relies on international pressure, advice, and monitoring to encourage compliance. Additionally, several bilateral and multilateral trade agreements cover labor and environmental standards. For example, the labor side agreements were a critical element of the North American Free Trade Agreement (NAFTA). 
The goal of this paper is to critically evaluate the case for and against international labor standards. The next section reviews theoretical perspectives on labor standards and discusses issues related to the use of international trade linkages as a lever to influence labor standards. My main conclusion is that there are valid arguments on both sides of this debate. Thus, empirical evidence and experience are necessary to sort out the validity of the case for and against international labor standards and determine the desirability of linking labor standards to trade policy. The following section provides evidence on the political economy of child labor standards by studying the sources of support for legislation currently before the United States Congress that would ban importation of products made with child labor. Specifically, this section asks whether there is evidence that support for international labor standards stems from a desire to protect constituents from foreign competition. Next, I examine how the prevalence of child labor varies across countries according to levels of economic development. Not surprisingly, child employment rates decline sharply with income per capita. Last, I look at compulsory schooling laws, which are often a complementary, or alternative, policy to banning child labor. This analysis finds a tremendous amount of noncompliance with minimum schooling laws in developing countries.

\section{Theoretical Perspectives on International Labor standards}

A variety of theoretical arguments have been made for and against international labor standards. Some of these arguments are very old; others have been developed more recently. 
Efficient, competitive markets and the political economy model

A starting point for most economic analyses is the efficient, competitive model. Ehrenberg 1994 provides a nice overview of the implications of this model for international labor standards. In this model the total compensation (monetary and nonmonetary) workers receive equals their marginal contribution to the value of output. Each country's economy operates at a Pareto optimal position - no government policy will make a person better off without making another person worse off. Wage differentials compensate workers for the varying health risks and other disamenities they face on the job. Child laborers are assumed to be paid a wage commensurate with their contribution to output and to rationally choose between working and pursuing formal education or other activities. Labor standards in this model cannot raise the welfare of a nation as a whole, although they can make some workers better off at the expense of other workers, consumers, or employers. Ehrenberg (1994) and others argue that the cost of meeting standards is likely to be borne by workers, in the form of lower wages or devalued currency. This model is clearly a simplified view of the world, but it may capture some critical effects of introducing labor standards.

Trade between nations is based on comparative advantage. Countries specialize in the activities in which they have a comparative advantage in terms of physical or human resources. The more different are nations, the more they stand to gain from trading with each other. A reduction in trade barriers will create winners and losers in each country, although under fairly general conditions the gain to the winners will exceed the loss to the losers in each country. If a common set of labor standards were imposed on 
countries, according to this model the net gains from trade will be reduced. Prices of goods produced by labor-intensive technologies will rise if labor standards raise the cost of labor. Because developed countries tend to specialize in capital-intensive goods, this model predicts that the welfare of consumers in developed nations will decline if minimum labor standards are imposed worldwide, although the welfare of workers in labor-intensive industries in industrial nations may increase. (See Brown, Deardorff and Stern 1993 for a theoretical treatment of these and related issues.) Why do some industrial countries seek to impose international labor standards in this model? A widely held view is that labor standards are pursued by vested interests in these countries (labor unions, employers in certain industries) to prevent competition from developing countries based on comparative advantage (Hansson 1983, Bhagwati 1994, and Srinivasan 1994). For example, if child labor is used extensively in the textile industry in developing nations, then textile companies in industrial nations would benefit from an international ban on child labor. The textile industry in industrial nations will have an incentive to lobby for such policies. Srinivasan (1994) argues that "the demand for linkage between trading rights and observance of standards with respect to environment and labor would seem to arise largely from protectionist motives." I call this the prevailing political economy view of international labor standards.

Redistribution

An efficient private market may fail to generate a distribution of incomes or working conditions that is desired by the public. For example, wages for the 
least skilled workers may be so low as to impoverish a large segment of the workforce. Society may wish to redistribute income toward low-income people. Any redistribution in an economy that is operating at the efficient frontier will entail some deadweight loss, ruling out lump-sum transfers. For example, it is often argued that a minimum wage reduces the employment of some groups of workers (causing deadweight loss). But a minimum wage may still be desirable because the total income of low-paid workers increases if the elasticity of demand for labor is less than one. The desirability of labor standards as a redistributive tool would depend on the society's interest in redistributing income and on the comparative strengths and weaknesses of other programs that could be used to redistribute income.

The comparative advantage of a minimum wage, for example, depends critically on the elasticity of labor demand-the lower the elasticity, the smaller the distortion created by a minimum wage. ${ }^{2}$ My reading of the evidence for the United States, where most minimum wage workers are employed in nontraded goods sectors, is that employment would not be noticeably affected by a moderate increase in the minimum wage from its current level (Card and Krueger 1995). This conclusion may be very different in developing countries, however. An interesting recent paper by Squire and SuthiwartNarueput (1995) points out that the distortionary effect of a minimum wage and other labor standards may be diminished by endogenous compliance; when the efficiency loss is great, firms and workers have a stronger incentive to avoid the minimum wage through noncompliance or by moving to the uncovered sector. It is also important to compare the net benefits of labor standards with the net benefits of feasible alternative policies. Often, labor standards are not targeted to the poorest in society because the very poor are either not 
working or working in the informal sector, which does not abide by labor standards.

Much economics research focuses on the adverse side effects of public policies, to the exclusion of the effectiveness of the policies themselves. But just because policy interventions may have negative side effects is not in itself reason to conclude that the interventions are undesirable. These unintended consequences must be weighed against the intended consequences. An analogy to medicine is instructive. Chemotherapy is used to treat certain forms of cancer, but chemotherapy has adverse side effects. To treat these adverse side effects, doctors often prescribe additional medications, that themselves may have some adverse side effects. Similarly, multiple economic policies to bring about a desired level of redistribution may be more effective than a single policy.

Market failure

Some observers have emphasized market failures, especially in the labor market, as a justification for international labor standards. ${ }^{3}$ Labor standards may improve efficiency as well as equity if the market has failed. There are several possible reasons for market failures. Information in the labor market is often imperfect and asymmetric. For example, employees may lack adequate information about safety conditions. Employers may have an incentive to conceal safety risks, especially in casual labor markets in which reputational effects are small.

Unequal market power may also lead to market failure. Forced labor is an obvious example in which employers have market power and the abolition of 
forced labor would enhance economic efficiency. As another example, child laborers are often not perfectly mobile, which would confer some monopsony power to employers. If employers have monopsony power over workers, a skillfully set minimum wage could increase employment, wages, and welfare. Of course, if the minimum wage is set too high, it could reduce employment and efficiency, even in a monopsonistic labor market.

A related issue concerns discrimination, broadly defined to mean the existence of equally productive workers who are paid different wages based on characteristics unrelated to their productivity (such as race or gender). In a perfectly competitive market there is a strong economic incentive against discrimination because nondiscriminating firms will gain a competitive advantage. Yet social customs and market power may enable discrimination to persist (Akerlof 1976). The elimination of discrimination would improve economic efficiency, as well as be morally justified. Swinnerton (1996) argues that "core" labor standards, such as prohibitions against forced labor and discrimination, are always economically efficient, while other standards (such as a fixed minimum work age) are efficient in some countries and inefficient in others, depending on the level of development.

Externalities, resulting from the failure of the parties involved to internalize all the costs and benefits of particular actions, could also lead to market failure. Although externalities probably provide a stronger justification for environmental standards than for labor standards, they may also justify some labor market standards.

Recent economic modeling of standards focuses on potential multiple equilibria (Fields 1995 and Basu and Van 1996). The economy could settle down in one of several equilibria, some of which may be pareto inferior to others. 
Standards could potentially move the economy to a more efficient equilibrium, or they could reinforce an inefficient one. Unfortunately, little evidence is available to test whether standards help overcome market failures.

Race to the bottom

One version of the race to the bottom model assumes that in some countries labor is exploited by the political or economic leadership. Such exploitation may take the form of forced labor. If some countries exploit labor in this fashion, other countries will be induced to lower their labor practices and standards as well because of competition, or suffer higher unemployment. Echoing Gresham's law, Marshall (1994) argues that "a basic principle of highly competitive markets is that bad standards tend to drive out the good." Collectively, people in all countries could be better off with a minimal level of labor standards if some countries exploit labor, and this exploitation leads to lower labor standards abroad. ${ }^{4}$

Freeman (1994) and Ehrenberg (1994) argue that, as a practical matter, race to the bottom is unlikely. As evidence, they note that states in the United States have persisted with widely divergent labor standards for decades. This is certainly true, and it is improbable that a race to the bottom will cause all countries to converge to a common, negligible set of labor standards. Nonetheless, on the margin a low-level of standards in one country could put downward pressure on standards in other countries, especially as the world trading system becomes more integrated. ${ }^{5}$ For example, Newt Gingrich and Pat Buchanan both argued against a minimum wage increase in the United States because the Mexican minimum wage is less than 
one-quarter the United States level.

Consumer sovereignty

Consumers may consider the process by which products are made an important attribute of the product. Thus, Freeman 1994 argues that consumers often are willing to pay more for products that are made in socially responsible ways (without forced labor, for example), and this desire is likely to increase with income. A 1994 poll by Marymount University provides some support for Freeman's view: 84 percent of U.S. shoppers said they would be willing to pay $\$ 1$ extra for a \$20 garment if it were made without sweatshop labor (Haq 1996). Freeman concludes that a proper role of government is to provide information regarding "socially responsible" companies, to induce companies to provide better working conditions by altering market demand for their products. In its recent campaign against sweatshop labor, the United States Department of Labor tried exactly this tactic, to some effect.

Taken to an extreme, individuals in one country may feel it is morally unacceptable for a country to gain a comparative advantage based on certain labor practices, such as forced labor (Charnovitz 1992 and Bhagwati 1994). Just as individuals may choose not to buy certain products because they dislike attributes of the product, society may collectively express these preferences by pursuing national and international labor standards. It may or may not be more efficient for the government to collect the necessary data to pursue these preferences through international labor standards.

Rodrik (1995) draws an interesting parallel between international labor standards and restrictions on domestic technology. Formally, liberalized 
trade is equivalent to an improvement in technology, because trade enables goods to be "produced" at lower costs. Rodrik notes that nations often restrict the type of technology that domestic firms can use. Labor standards are a type of restriction on technology. Rodrik argues, "It is difficult to see why a particular sort of technology, that which is embodied in international trade, should be immune from the same type of considerations." From the standpoint of a worker in an advanced country who is displaced by an under-age child, it makes little difference if that child works at home or abroad.

Enhance labor market institutions

Some labor standards are desirable because they enhance the efficient operation of the labor market. For example, Freeman (1992), Marshal1 (1994), and others argue that protected collective bargaining could enhance the operation of the labor market. Piore (1994) argues that labor market standards enhance the stability of social relationships, and may lead to the evolution of more efficient production strategies.

Labor market institutions may have positive spillovers to the rest of society. It is arguable that solidarity and western pressure for free trade unions in Poland had as much of an impact on the rise of democracy and markets in Central and Eastern Europe as the United states military buildup. Many argue that policies that protect free and democratic unions have collateral political benefits. Take the U.S. ordeal of forced labor as another example. In the nineteenth century European countries made no effort to link trade to the abolition of slavery. Had Britain refused to purchase cheap U.S. cotton 
produced with slave labor, one can only speculate about whether the bloody Civil war could have been averted or shortened. When judged against the small increase in prices that may result from international labor standards, the collateral political and social benefits could be quite large.

\section{Why Link International Trade And Labor Practices?}

Preliminarily, it can be noted that in a well-functioning democracy, the government would have a strong incentive to set labor standards so as to overcome market failures, achieve desired redistribution, and enhance efficiency. Each country therefore would have a strong incentive to choose the "right" level of labor standards, given its norms, culture, and level of economic development, because by choosing the right standards the government maximizes social welfare and increases its chances of being reelected. For the country itself the optimal labor standards will depend on the significance of market failures, the comparative efficacy of standards, the desired level of redistribution, and other factors. Technical assistance and nonbinding advice may help countries establish the set of standards that is best for them, but if the political system functions well, outside influences are unlikely to enhance welfare by interfering with labor standards in sovereign countries.

An exception to this optimistic conclusion would occur if the political system in a particular country is not responsive to the welfare of its citizens. For example, as noted above, if the leadership of a nation exploits its workers (say through forced labor), this exploitation will put downward pressure on wages and working conditions in other countries (although 
consumers will face lower prices of goods). International pressure for labor standards could improve the welfare of workers in both nations if one nation unfairly exploits its workers. This observation underscores U.S. Labor Secretary Robert Reich's 1994 position that, if a country "lacks democratic institutions and fails to disseminate the benefits of growth, other countries might justifiably conclude that low labor standards are due not to poverty itself, but to political choices that distort development and warp the economy's structure."

If one assumes that minimal labor standards are desirable, what are the arguments for or against using international trade as a point of leverage to enforce minimum labor standards in other countries? Some trade economists have taken the extreme position that any policy that interferes with free trade must be disguised protectionism and must be bad. I have six pragmatic observations on this issue.

1. Multinational and other organizations often play an informational and monitoring role insofar as labor standards and working conditions are concerned. Better information is expected to political and economic markets work better.

2. If the pressure for standards emanates solely from a desire to protect workers in advanced economies, the standards may not be in the best interest of the less advanced economies. In particular, a concern is that developing countries will be pressured to accept standards that exceed their economic capacity.

3. It is unlikely, in any event, that minimal labor standards will provide much protection to workers in industrial countries. The gap in wages and working conditions for unskilled workers 
between advanced and less advanced economies is so great that any realistic set of minimal labor standards is unlikely to have much impact on trade flows (Grossman and Krueger 1993). If the sole goal of labor standards is to help workers in industrial countries, there are probably more direct and more efficient ways than international labor standards.

4. Ehrenberg (1995) proposes that industrial countries compensate developing countries to accept and enforce higher labor standards. Whatever the economic merits of this idea, it is unlikely to attract much support in industrial countries, which can barely muster the political support for trade agreements or for aid to developing countries.

5. Labor standards are often a subject of bargaining in trade negotiations. Presumably, a well-intentioned government will not accept an agreement unless, in total, it is expected to make the country better off. No country has the right to impose its laws on a sovereign nation. Yet trade agreements are voluntarily agreed to. Side agreements may help produce a more equitable distribution of the surplus resulting from expanded trade. The NAFTA side agreements, which create institutions to ensure that parties to the agreement enforce their own labor laws, may serve as a model. Also note that if, as expected, trade agreements increase national income, countries will be able to afford more stringent labor standards following the agreements. Since the demand for labor standards tends to rise with national income, many countries will endogenously desire to strengthen and enforce 


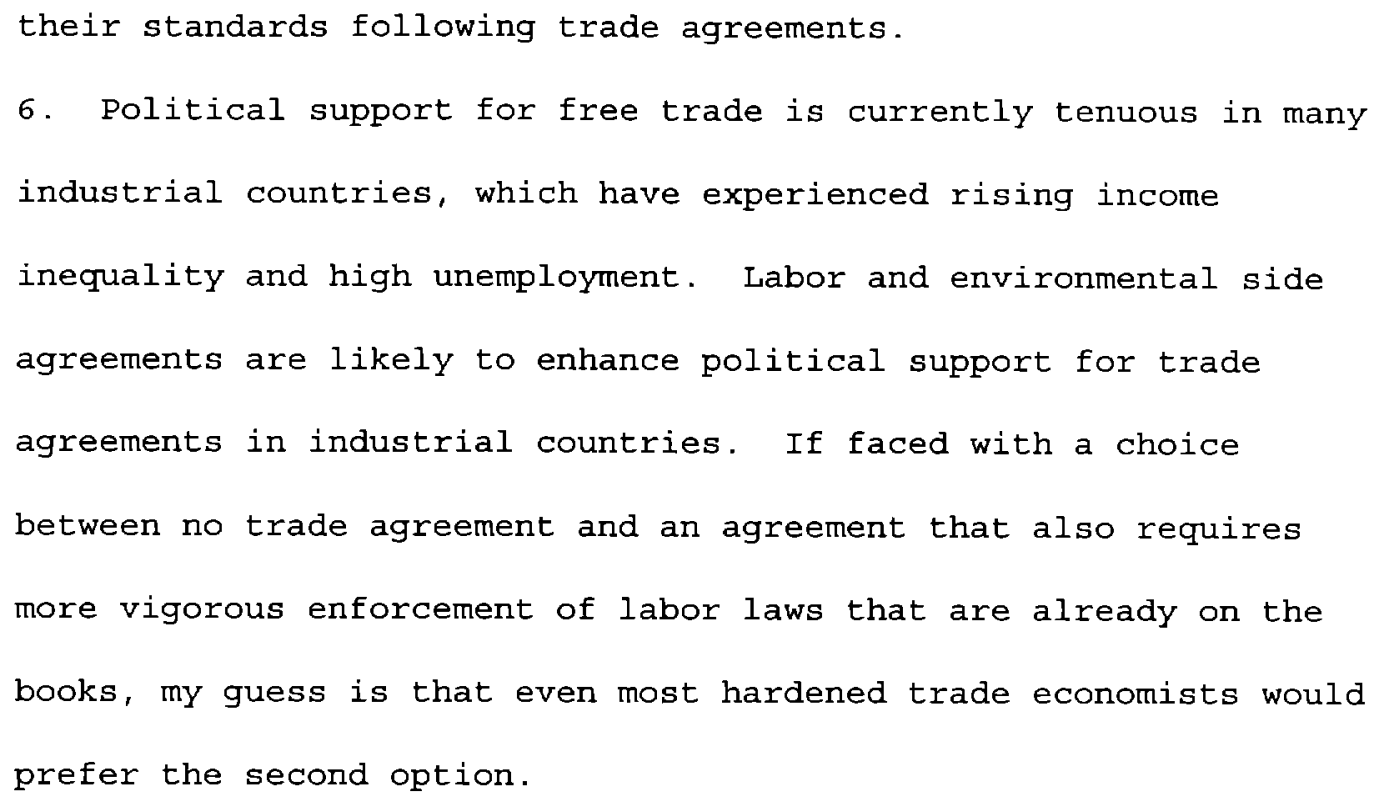

\section{Disguised Protectionism?}

Although a major concern with international labor standards is that they may be used as an excuse to inefficiently protect interests in industrial nations from competition from developing countries, there is surprisingly little empirical evidence one way or the other-on this issue. One way to investigate whether legislators support international labor standards in an effort to protect domestic interests would be to examine whether support for such legislation is greatest among legislators whose constituents would benefit most from international labor standards. This hypothesis is particularly difficult to test, however, because labor standards are typically bundled with other trade legislation and rarely come up for a separate vote, such as was the case for the NAFTA side agreements.

One bill that provides an opportunity to study the determinants of support for international labor standards is the proposed Child Labor 
Deterrence Act of 1995 (S. 706 and H.R. 2065). If passed, this legislation would prohibit the importation to the United states of goods produced abroad with child labor. ${ }^{6}$ Senator Tom Harkin (D-Iowa) has sponsored this legislation in the Senate, and Representative Barney Frank (D-Massachusetts) in the House. Although the bill has not come to a vote, it has thirty-five additional cosponsors in the House of Representatives and seven in the Senate. Cosponsoring legislation is an indication of strong support for the bill. I have assembled a data set to study the determinants of support for this tradelinked child labor standard.

Specifically, I relate whether a member of the House of Representatives is a cosponsor of the Child Labor Deterrence Act to characteristics of the representatives' districts and the representatives' political background. 7 Plausibly, constituents with a low level of education (and their employers) are those most likely to benefit directly from this act because imported products made with child labor are most likely to compete with domestic products produced by less-educated workers in the United states. So if support for banning imports of products made with child labor in part represents a concealed desire on the part of representatives to protect their constituents from foreign competition, one would expect support for this legislation to be strongest among legislators who represent districts with relatively many high school dropouts. To test this proposition, I collected data on the share of the population age twenty-five and over with less than a high school degree for each Congressional district. ${ }^{8}$

Results of estimating several linear probability models are reported in table $1 .^{9}$ The dependent variable equals one if the representative is a cosponsor of the Child Labor Deterrence Act of 1995, and zero if he or she is 
not. In addition to the share of high school dropouts, I control for a number of other variables. The union rate variable measures the proportion of the workforce in the state that belongs to a union, based on Hirsch (1994). Votes on NAFTA, the General Agreement on Tariffs and Trade (GATT), party affiliation, the representative's rating by Americans for Democratic Action $(A D A)$, the popular vote for the representative in the 1994 election, and the number of terms served by the representative are all from Duncan and Lawrence (1995). The sample consists of 434 members of the 104 th Congress. (The sample size is not 435 because one seat was open in 1995.)

The results indicate that representatives from districts with a high concentration of high school dropouts are less likely to cosponsor the Child Labor Deterrence Act. And the magnitude of the effect is fairly large: going from a district with 10 percent high school dropouts to one with 30 percent lowers the probability of sponsoring the Act by roughly $B$ percentage points, other things equal. This finding is contrary to what I would expect from a simple political economy model that says members of Congress whose constituents benefit most from the Child Labor Deterrence Act are most likely to support the Act.

Several of the other variables reported in table 1 are also of interest. First, representatives from states that have a higher union rate are more likely to cosponsor the Child Labor Deterrence Act. There are two plausible explanations for this finding: (1) workers in the unionized sector receive rents, and unions therefore try to prevent foreign competition from eroding those rents; (2) unionized workers and their representatives are concerned about labor rights generally. As discussed below, because unionized workers are unlikely to compete with child labor, the first explanation is 
questionable.

For representatives who also served in the lo3rd Congress, I can examine the relationship between support for NAFTA and GATT and support for the Child Labor Deterrence Act. Specifically, columns 2 and 3 include dummy variables which measure whether the representative voted for NAFTA and for GATT, for NAFTA and against GATT, and for GATT and against NAFTA. Interestingly, the results indicate that representatives who supported NAFTA and GATT were 11 percentage points less likely to support the Child Labor Deterrence Act of 1995 than were representatives who opposed both NAFTA and GATT. Thus, those who opposed expanding trade opportunities through NAFTA and GATT were also more likely to support the Child Labor Deterrence Act. This finding suggests that those who support international labor standards are more likely to favor protectionist policies generally, but the findings for the education variable make it unclear whether those protectionist policies are in the narrow interest of their constituents. Below I examine the determinants of support for NAFTA and GATT to gain further insights into this issue.

Members of the Democratic Party (which is defined to include the one Independent member of Congress) are more likely to support child labor standards. Indeed, none of the cosponsors of the Child Labor Deterrence Act in the House is a Republican (although two Republicans cosponsored the bill in the senate). In columns 4-6 I reestimated the models for the subsample of Democrats. The results for this subsample are qualitatively similar; most important, districts with relatively many poorly educated workers continue to be less likely to support the Child Labor Deterrence Act.

Support for international labor standards may just reflect the representatives' ideology. Unfortunately, ideology is hard to define and 
quantify. The ADA rating measures the "liberalness" of the member's voting record, as reflected by votes for bills supported by the ADA. This variable, which is intended to reflect the ideology of the member, is positively associated with support for the Child Labor Deterrence Act. ${ }^{0}$ Except for the dummy variable measuring party affiliation-which becomes statistically insignificant-including this variable hardly alters the effect of the other variables. Last, notice that the variables measuring the representative's share of the vote in 1994 or number of terms in office both have statistically insignificant effects in all of the specifications.

Comparison with NAFTA and GATT votes

It is useful to contrast the model results reported here with comparable models of the determinants of support for NAFTA and GATT. Specifically, I ask whether representatives from districts with many less educated workers were more or less likely to vote for NAFTA and GATT. The first two columns of table 2 contain linear probability models in which the dependent variable equals one if the representative voted in favor of NAFTA, and zero if he voted against. The next two columns contain the same models for GATT. The sample consists of the subset of Congressmen who were in office in 1994 and 1995 . Even though the vote on GATT was held in a lame duck session of Congress, we would expect this sample to be responsive to their constituents' interests because it consists exclusively of members who returned to Congress.

The independent variables are much more successful at explaining support for NAFTA than for GATT. ${ }^{11}$ Interestingly, representatives with a high fraction of less-educated workers in their district are more likely to oppose 
NAFTA and GATT, even though they are less likely to support international child labor standards. This finding suggests that the fraction of less educated workers in a district does at least partially reflect a constituency base that stands to benefit from protectionist policies.

A higher union rate and membership in the Democratic party are also strongly negatively related to votes for NAFTA. MCArthur and Marks (1988) similarly find that a high union rate and union political contributions are strong predictors of votes for the 1982 automobile industry domestic content bill, and Baldwin (1985) finds that union political contributions are correlated with opposition to the Trade Act of 1974 . The finding of a negative relationship between unionization and support for NAFTA is not surprising, as the AFL-CIO strongly opposed NAFTA. The ADA rating is insignificantly related to support for NAFTA or GATT, but in other results I find that the AFL-CIO's political rating scale has a significant negative effect on votes for NAFTA and GATT. 12

A consideration of the major players in the legislative battles over NAFTA and GATT yields some additional insights. Senator Earnest Hollings (D-South Carolina) led the unsuccessful campaign against GATT, although he did succeed in postponing the vote to a lame duck session. Notably, a majority of the South Carolina Congressional delegation also voted against GATT and NAFTA. It was widely believed that senator Hollings was motivated by a concern to protect textile and apparel firms, which are major employers in south Carolina. The textile and apparel industry is also a major employer of children abroad. Yet not one of the current cosponsors of the child Labor Deterrence Act of 1995 is from South Carolina. Since South Carolina stands to benefit as much as any state in the nation from a ban on imports produced by 
child labor, the lack of support by South Carolina representatives also suggests that support for the act is not motivated by disguised protectionism.

A broader literature on the political economy of tariffs also finds that opposition to trade liberalization is related to constituents' economic interests, similar to results of the NAFTA and GATT regressions. Baldwin (1985), for example, finds that representatives from districts with relatively many workers in import-sensitive industries were more likely to oppose the Trade Act of 1974. In related work Tosini and Tower (1987) examine support for the Textile Act of 1985, which would have established quotas to restrict imports of textile goods to the United States. Legislators were much more likely to support this bill if their district had a high percentage of workers in the textile industry and if they received funds from the Amalgamated Clothing and Textile workers Union, while they were more likely to oppose the bill if their districts had a high percentage of workers in export industries. Thus although support for child labor standards does not appear to be related to constituents' economic interests, support for tariffs and quotas does appear to reflect constituents' economic interests.

Interpretation

There are a variety of ways of interpreting these results. In my view, however, there is scant support for the most direct test of the hypothesis that advocacy of international labor standards reflects disguised protectionism. Representatives from districts that stand to gain the most from the Child Labor Deterrence Act-those with relatively many unskilled workers are least likely to cosponsor the act. Moreover, a higher fraction of 
less-skilled workers is associated with opposition to NAFTA and GATT (see table 2). An alternative explanation for these results is, as Freeman (1994) argues, that demand for international child labor standards is a normal good (meaning that demand rises with income) and that people with higher socioeconomic status (higher education) select representatives who are more supportive of placing limits on child labor. It is, of course, possible that support for other types of labor standards represents disguised protectionism. But in view of the results for the Child Labor Deterrence Act, it is incumbent on those who view international labor standards as disguised protectionism to provide evidence to support that conclusion.

Another issue concerns the strong effect of the union rate variable on the Child Labor Deterrence Act. One may be tempted to conclude from this result that unions support international labor standards out of self-interest (to raise the incomes of their members). Studies of legislative support for the minimum wage have reached this conclusion from similar evidence; for example, Bloch (1980) and Cox and Oaxaca (1981) interpret a positive correlation between a state's union rate and support for a minimum wage increase as evidence that (generally high-wage) unionized workers benefit from minimum wage legislation because union workers are substitutes for minimumwage workers. However, I find this interpretation strained in this case because unionized workers are not obvious beneficiaries of a ban on imports made with child labor and certainly stand to benefit less than high school dropouts from such a ban. An alternative interpretation is that unions are pursuing policies that strengthen worker, rights generally, rather than merely maximizing the self-interest of their members.

My own experience suggests to me that union leaders actively support 
labor standards, and that, in many instances, labor standards would not receive any attention if it were not for unions. U.S. labor unions have pressed the Clinton Administration to add labor standards to the agenda of international summits, supported stronger labor side agreements in NAFTA, and lobbied Congress to increase the budget of the ILO. Yet in many cases I do not think that the union leadership effectively furthers its members' narrow interests by pushing these policies. Indeed, in many instances I am surprised that the AFL-CIO uses its limited political capital to press for international labor standards that are of little benefit to its members, when it could instead pursue policies of much greater direct benefit to its membership. For example, in the recent AFL-CIO presidential election, Lane Kirkland was roundly criticized for pursuing international labor standards at the expense of domestic union bread and butter issues. This is not to suggest that unions never pursue legislation that benefits their membership at the expense of others. They do. But it does suggest that one cannot leap to the conclusion that a positive association between support for international labor standards and unionization proves that unions support standards for the narrow reason of enhancing the position of their members.

Two final points are in order. First, a conclusion that support for a child labor ban does not result primarily from disguised protectionism does not mean that such a standard is economically efficient or desirable. Second, if support for the ban were motivated primarily by disguised protectionism, it might still be economically efficient. To evaluate the desirability of standards, it is necessary to examine their actual impact. Are labor standards complied with? What is their economic effect? Are there better ways of achieving the same ends? These questions are partially addressed in 
the next section, in the context of child labor and compulsory schooling.

\section{Child Labor Standards And Compulsory schooling}

Many countries have laws prohibiting "exploitative child labor" and the employment of "very young" children. It is not economically efficient to exploit child or other labor. Furthermore, very young children may not have the ability to make rational employment and schooling decisions. Although left to their own, children may make irrational decisions, their families will often help them to make sensible choices. The primary economic approach to modeling child labor is to assume that rational time allocation decisions are made jointly by children and their families. As Grootaert and Kanbur 1995 emphasize, child labor standards could alter the bargaining power and welfare of children, while at the same time weakening the economic position of their families. Basu and van (1996) note that a ban on child labor will push up the wage of adults, possibly to the point where families are wealthy enough that they no longer want their children to work. On the other hand a prohibition against child labor in one sector could force children into less desirable activities, such as the underground economy.

The effect of government policy toward schooling on child labor supply has largely been ignored in this literature. If the government provides higher quality education, the incentive for students to acquire education and postpone work will be greater. If schools are not available nearby, or are of low quality, then work is a more attractive option. It is possible for children to make rational decisions to work instead of attend school based on their existing set of schooling opportunities, but the schooling opportunities 
may be suboptimal.

How widespread is child labor? Child labor is difficult to define and measure. Often, statistical agencies do not collect information on labor force status for children below the minimum work age. Based on a collection of data from 124 countries, the ILO estimates that some 78.5 million children age fourteen and under worked worldwide in 1990 (Ashagrie 1993). The ILO convention on child labor (Convention 138) sets the minimum work age at fifteen, but permits a lower age for developing countries. (The ILO convention also permits light work for children age thirteen to fifteen, provided it does not interfere with educational activities.) Forty-six countries have ratified this convention. However, the high rate of employment of children under fifteen suggests a fair amount of noncompliance with this standard in many countries.

Figure 1 illustrates an obvious point: employment of young children is common in low-income countries and uncommon in high-income countries. ${ }^{13}$ The figure utilizes data collected by the ILO on the percent of ten to fourteen year old children who were employed in 1995. Data on GDP per capita in 1992, which are shown with a logarithmic scale, are from Penn World Table 5.6. The steep downward sloping relationship indicates that child labor declines as one moves from low-income to high-income countries. Employment rates are highest for children in Burundi (49 percent), Uganda (45 percent), and Rwanda (42 percent). In countries where GDP per capita exceeds $\$ 5,000$, such as most of Western Europe and North America, employment of young children is negligible. Cross-country differences in log GDP per capita and its square account for an astounding 80 percent of the variability in child employment rates worldwide. Child labor is a necessary source of production and income in many 
developing countries. The ILO survey finds that nearly 80 percent of child laborers work in the agriculture, hunting, forestry, and fishing sectors. In many cases this work may not interfere with the normal social and educational development of children. While child labor is considered a necessity for economic survival in some societies, it is considered an abomination in others. From figure 1 it is obvious that it would be difficult to enforce a single minimum work age in all countries.

Another important lesson is that a higher level of economic development is associated with a decline in child labor. Many goods are normal goods, meaning that their consumption rises as income rises. Child labor could be thought of as a "normal bad," a practice that is tolerated when societies are poor but not when they are wealthy. Thus, one would expect more developed economies to have stronger child labor standards, and they typically do. Also note that according to ILO figures the number of children under age fifteen who are working declined by 11 percent between 1980 and 1990 (although much of this decline may well represent a reporting phenomenon). Economic growth appears to be an important way to reduce child labor. If trade agreements increase the wealth of nations, then developing countries that are a party to such agreements would be expected to more readily adopt child labor standards after trade has expanded.

Compulsory schooling

Compulsory schooling laws and minimum work age requirements are typically complimentary policies. Weiner (1991) observes that "compulsory primary education is the policy instrument by which the state effectively removes 
children from the labor force." The ILO recommends full-time schooling or vocational training at least until the minimum work age. A number of authors have recently suggested that compulsory schooling be emphasized as a policy to reduce child labor instead of minimum work age requirements. Given the importance of compulsory schooling laws, I examined evidence on compliance with compulsory schooling, using data from the 1990-91 waves of the World Values Survey, a set of international cross-sectional surveys launched by the European Values Systems Study Group. The survey is designed for international comparisons, and in each country respondents were asked for the age at which they completed (or will complete) full-time education.

Table 3 reports the school leaving age distribution for individuals born between 1959 and 1974 in selected low-income countries, and for comparison in the United Kingdom and the United States. The table indicates a tremendous amount of noncompliance with compulsory schooling laws. In Brazil fully 80 percent of youngsters left school before reaching their thirteenth birthday, even though the compulsory schooling age is fourteen, and in Mexico and Portugal one-quarter of the population left school before reaching the minimum schooling age. In India, where the compulsory schooling law varies across regions and is often as low as eleven, 40 percent of the population left school at age 12 or earlier. Weiner (1991) argues that the lack of commitment to a national compulsory schooling policy in India is a major reason why a large share of the population is illiterate. In the United states, where sixteen is the most common compulsory schooling age, very few students leave school before age seventeen. In the United Kingdom half of students leave school at age sixteen, the compulsory age.

Although there is clearly noncompliance with compulsory schooling laws, 
the laws still may lead to higher educational attainment than would otherwise be the case. Table 4 documents that the compulsory schooling age clearly has affected educational attainment in the United Kingdom. The compulsory schooling age was raised from fourteen to fifteen in 1947 and then from fifteen to sixteen in 1973. A comparison of the schooling leaving age distribution for three cohorts-one covered by the age fourteen law, one covered by the age fifteen law, and one covered by the age sixteen law shows that for each cohort the modal school leaving age equals the minimum compulsory level. Moreover, for each cohort no more than 5 percent of individuals leave school before reaching the minimum age. Harmon and walker (1995) similarly find that educational attainment shifted out with the increases in the compulsory schooling age in the United Kingdom. In developing countries it is less clear that the compulsory schooling age has much effect on educational attainment. None of the lower-income countries in table 3 shows much of a spike in school completion around the compulsory schooling age. In Brazil child labor and low educational attainment are particularly a problem. An estimated 10 percent of Brazilian children work for their own or their family's survival on the streets (Myers 1988). Brazil increased its compulsory schooling age from eleven to fourteen in 1971. Yet table 5 shows there is hardly any difference in school leaving ages for the younger cohort, which was covered by the age fourteen law (born after 1962) and the older cohort (born before 1958), which was covered by the age eleven law. Regardless of the compulsory schooling age, roughly 85 percent of children left school before reaching the age of fourteen. In the United Kingdom and the United states compulsory schooling has been found to lead to higher earnings (Angrist and Krueger 1991 and Harmon and 
Walker 1995). These studies find that the earnings payoff to years of compulsory schooling tends to exceed the payoff to years of schooling beyond the compulsory level. For several reasons policies that increase educational attainment in developing countries are likely to have large rewards as well. First, Psacharopoulos (1994) Einds that primary education pays a higher return than secondary and higher education in developing countries, and compulsory schooling laws typically pertain to primary schooling. Second, fertility rates tend to decline with maternal education in developing nations. And third, infant and child mortality tend to decline with maternal education as well (World Bank 1995a).

Compulsory schooling laws, by themselves, are unlikely to increase educational attainment and to reduce child labor. An increase in educational attainment requires the availability of adequate educational facilities, vigorous enforcement, and a commitment on the part of parents and policy makers to foster education. Compulsory schooling laws can form an important component of child labor policy, but unless communities have adequate schools and families have the financial wherewithal and will to send their children to school, there will be rampant noncompliance with compulsory schooling laws. More generally, low compliance with labor standards is often a major issue in developing countries (World Bank 1995b). If countries lack the capacity or will to enforce their existing labor standards, pressing them to adopt more stringent standards probably will have little effect. Recent efforts by the international community to encourage nations to enforce the laws that they already deem adequate seems to be a response to the low compliance. 


\section{Conclusion}

A review of the theoretical literature suggests that labor standards could enhance the efficiency of the labor market and improve the distribution of income in some situations, but could prove counterproductive for efficiency and equity in others. Interestingly, after surveying the unequal political power of employers and employees, Adam Smith (1776) concluded that "when the regulation, therefore, is in favor of the workmen, it is always just and equitable; but it is sometimes otherwise when in favor of the masters." In modern democratic countries, however, Fields's (1995) observation regarding labor standards may be more relevant: "There is no easy generalisation, and the 'less is better' view is as imbalanced on one side as is the 'more is better' view on the other."

Support for international labor standards in advanced nations does not necessarily represent disguised protectionism. Although a large literature finds that political support for tariffs and quotas at least in part reflects a desire to protect constituents' economic interests, the available evidence does not suggest that politicians support international labor standards out of a desire to further the narrow economic interests of their constituents. Thus, pressure for international labor standards cannot be dismissed automatically as disguised protectionism. Standards may or may not serve a useful purpose, but they must be evaluated on their merits.

Wealthier countries tend to have more stringent labor standards and better working conditions. In particular, economic development is inversely related to the use of child labor. The costs of labor standards are probably borne by the country with the standards, in the form of lower wages, higher product prices, or devalued currency. Many labor standards are normal goods, 
for which demand is likely to increase with economic growth. Policies that sacrifice economic growth could therefore have a negative effect on working conditions in the long run.

Unless there is a concerted effort to enforce standards, and unless the standards are appropriate for the economic conditions in a country, standards are unlikely to have much impact. If standards are set too high they tend to be widely ignored. Likewise, reliance on compulsory schooling laws as an alternative policy to labor market standards will have little effect unless they are enforced, sufficient schools are available, and school attendance is sufficiently valued by parents and children.

From an analytical standpoint there is much to be said for treating labor standards as normal goods, which are desired and consumed in greater quantity when income is higher. Although the political economy model does not adequately explain why some U.S. legislators support the Child Labor Deterrence Act, a view of labor standards as a normal good does. Representatives from districts that are higher up the socioeconomic ladder act as if their constituents have a stronger desire to avoid products made with child labor, even though such actions may require their constituents to pay more for the products they consume. Relatedly, wealthier societies tend to impose stronger labor standards on themselves and are less likely to use child labor. An important unresolved question is whether there are more efficient ways of satisfying individuals' demands for better treatment of workers and children than pressuring foreign nations to adopt labor standards or refusing to purchase goods made under conditions deemed substandard. For example, a wealthy nation could transfer income directly to poor children in developing countries, admit more immigrants, or subsidize employers to improve the 
conditions of workers and children in developing countries. But if labor standards enhance efficiency, the cost of exercising those tastes through international labor standards may not be very great. 


\section{$\underline{\text { References }}$}

Angrist, Joshua, and Alan Krueger. 1992. "Does Compulsory Schooling Affect Schooling and Earnings?" The Quarterly Journal of Economics 106 (4): 979-1014.

Akerlof, George. 1976. "The Economics of Caste and of the Rat Race and Other Woeful Tales." Quarterly Journal of Economics 90: 599-617.

Ashagrie, Kebebew. 1993. "Statistics on Child Labour: A Brief Report." Bulletin of Labour Statistics. Geneva, Switzerland: International Labour Office.

Baldwin, Robert. 1985. The Political Economy of U.S. Import Policy. Cambridge, Mass: MIT Press.

Basu, Kaushik, and Pham Hoang Van. 1995. "The Economics of Child Labor: Theory, Experience, and Legislation." Cornell University, Ithaca, N.Y.

Bhagwati, Jagdish. 1994. "Policy Perspectives and Future Directions: A View from Academia." In International Labor Standards and Global Economic Integration: Proceedings of a Symposium, Washington, D.C.: U.S. Department of Labor, Bureau of International Labor Affairs.

Brown, Drusilla, Alan Deardorff, and Robert Stern. Forthcoming. "International Labor Standards and Trade: A Theoretical Analysis." In Jadgish Bhagwati and Robert Hudec, eds., Harmonization and Fair Trade. Cambridge, Mass.: MIT Press.

Card, David, and Alan Krueger. 1995. Myth and Measurement: The New Economics of the Minimum Wage. Princeton, N.J.: Princeton University Press.

Charnovitz, Steve. 1992. "Environmental and Labour Standards and Trade." The World Economy 15 (3): 335-356.

Cox, James C., and Ronald L. Oaxaca. 1981. "The Determinants of Minimum Wage Levels and Coverage in State Minimum Wage Laws." In S. Rottenberg, ed., The Economics of Legal Minimum Wages. Washington, D.C.: American Enterprise Institute.

Davis, Donald. "Does European Unemployment Prop Up American Wages?" Harvard University, Cambridge, Mass .

Duncan, Philip, and Christine Lawrence. 1995. Congressional Quarterly's Politics in America, 1996: The 104th Congress. Washington, D.C.: Congressional Quarterly, Inc.

Ehrenberg, Ronald. 1994. Labor Markets and Integrating National Economies. Washington, D.C.: The Brookings Institution.

Fields, Gary. 1995. "Trade and Labour Standards: A Review of the Issues." Organization for Economic Cooperation and Development. Paris. 
Freeman, Richard. 1994. "A Hard-Headed Look at Labour standards." In Werner Sengenberger and Duncan Campbell, eds., International Labour Standards and Economic Interdependence. Geneva, Switzerland: International Labour Office.

Freeman, Richard. 1992. "Labour Market Institutions and Policies: Help or Hindrance to Economic Development?" In Proceedings of the World Bank Annual Conference on Development Economics. Washington, D.C.: World Bank .

Grootaert, Christiaan, and Ravi Kanbur. 1995. "Child Labour: An Economic Perspective." International Labour Review $134(2)$ : 187-204.

Grossman, Gene, and Alan Krueger. 1993. "Environmental Impacts of a North American Free Trade Agreement." In Peter Garber, ed., The U.S.-Mexico Free Trade Agreement. Cambridge, Mass.: MIT Press.

Hansson, Göte. 1983. Social Clauses and International Trade. New York: St. Martin's Press.

Haq, Farhan. 1996. "Critics Link Immigration Laws to Sweatshops." Inter Press Service, March 26.

Harmon, Colm, and Ian Walker. 1995. "Estimates of the Economic Return to Schooling in the U.K." American Economic Review 85 (5): 1278-86.

Hirsch, Barry T. 1993. Union Membership and Earnings Data Book 1993, Washington, D.C.: The Bureau of National Affairs, Inc.

Krueger, Anne. 1974. "The Political Economy of the Rent-Seeking Society." American Economic Review 64 (3): 291-303.

Maskus, Keith, Thomas Rutherford, and steven Selby. 1995. "Economic Implications of Changes in Labor Standards: A Computational Analysis for Mexico." University of Colorado, Boulder.

Marshall, Ray. 1994. "The Importance of International Labour Standards in a More Competitive Global Economy." In Werner Sengenberger and Duncan Campbell, eds., International Labour Standards and Economic Interdependence. Geneva, Switzerland: International Labour office.

McArthur, John, and Steven Marks. 1988. "Constituent Interests versus Legislator Ideology: The Role of Political Opportunity Costs." Economic Inquiry 26(3): 461-70.

Myers, William. 1988. "Alternative Services for street Children: The Brazilian Approach." In Assefa Bequele and Jo Boyden, eds., Combating Child Labor. Geneva, Switzerland: International Labor Office. 
Piore, Michael. 1994. "International Labor Standards and Business Strategies." In International Labor Standards and Global Economic Integration: Proceedings of a Symposium, Washington, D.C.: U.S. Department of Labor, Bureau of International Labor Affairs.

Psacharopoulos, George. 1994. "Returns to Investment in Education: A Global Update." World Development 22 (9): 1325-43.

Reich, Robert. 1994. "Keynote Address." In International Labor Standards and Global Economic Integration: Proceedings of a Symposium, Washington, D.C.: U.S. Department of Labor, Bureau of International Labor Affairs.

Rodrik, Dani. "Labor Standards In International Trade: Do They Matter and What Do We Do About Them?" Columbia University, New York.

Rosenzweig, Mark, and Robert Evenson. 1977. "Fertility, Schooling and the Economic Contribution of Children in Rural India: An Economic Analysis." Econometrica 45 (5): 1065-80.

Smith, Adam. 1776. An Inquiry into the Nature and Causes of the Wealth of Nations, New York: Random House Inc., Modern Library Edition, 1937.

Squire, Lyn, and sethaput suthiwart-Narueput. 1995. "The Impact of Labor Market Regulations." Policy Research Working Paper 1418. World Bank, Policy Research Department, Washington, D.C.

Srinivasan, T.N. 1994. "International Labor Standards Once Again!" In International Labor Standards and Global Economic Integration: Proceedings of a Symposium. Washington, D.C.: U.S. Department of Labor, Bureau of International Labor Affairs.

Swinnerton, Kenneth. 1996. "An Essay on Economic Efficiency and Core Labor Standards." Bureau of International Labor Affairs, Washington, D.C.

Tosini, Suzanne, and Edward Tower. 1987. "The Textile Bill of 1985: The Determinants of Congressional voting Patterns." Public Choice 54 (1): $19-25$.

Weiner, Myron. 1991. The Child and the State in India. Princeton, N.J.: Princeton University Press.

World Bank. 1995a. Priorities and Strategies for Education: A Review. Washington, D.C.: The World Bank.

World Bank. 1995b. World Development Report: Workers in an Integrating World. New York: Oxford University Press. 


\section{Notes}

1. Some observers draw a distinction between labor standards (such as minimum work ages) and labor rights (such as the right to bargain collectively). Although this distinction is meaningful, for this paper $I$ will use the term labor standards to cover both standards and rights.

2. Competition over rents created by redistributionary policies may also reduce efficiency, as resources are devoted to rent-seeking rather than production (see Krueger 1974).

3. The World Bank (1995b) lists several market failures as a rationale for labor standards. Maskus, Rutherford, and Selby (1995) provide a simulation of the effect of labor standards in Mexico assuming that workers are misinformed about work-related hazards.

4. Davis (1996) provides an interesting theoretical model in which Europe is assumed to have a binding minimum wage and the United States is assumed to have flexible wages. He predicts that Europe incurs enough unemployment to raise the wage of low-skilled United States workers to the European minimum wage if trade arbitrages goods prices between the countries.

5. Freeman (1994) writes, "I do not accept the premise of some that bad standards drive out good standards. Any country that wants higher Labour standards for itself can have them... if it is willing to pay." My point is that lower standards abroad may alter the price that the country will have to pay.

6. The Child Labor Deterrence Act of 1995 would urge the President to seek an agreement with other governments to secure an international ban on trade in goods produced by children under age fifteen. Additionally, it would require the secretary of Labor to identify foreign countries that do not comply with national laws that prohibit child labor and that utilize child labor in export products. After consultations with the U.S. Trade Representative and Secretaries of state, Treasury, and Commerce and at least one public hearing, the importation of such products from these countries could be prohibited.

7. With only seven cosponsors in the senate, this type of statistical analysis does not make much sense for the 100 members of the Senate.

8. This variable was derived from the STF3 file of the 1990 Census, which pertains to the 103rd Congress.

9. Since the dependent variable equals either zero or one, and the mean is rather low, a linear probability model is not strictly speaking appropriate. To partially address this issue, I have reported standard errors that correct for heteroskedasticity. More important, I also have reestimated the regressions using a logistic model and found qualitatively similar results. For simplicity, I report the linear probability models.

10. Results were quite similar when I used the AFL-CIO's political rating scale instead of the ADA rating. 
11. Indeed, a chi square test finds that the variables in the GATT equations are jointly statistically insignificant.

12. This may result, in part, because voting on NAFTA enters into the AFL-CIO's evaluation criteria, however.

13. The data used in Figure 1 were kindly provided by Kebebew Ashagrie of the ILO. Numerous microdata studies have found that child labor is negatively related to family income within countries (Rosenzweig and Evenson 1977). 


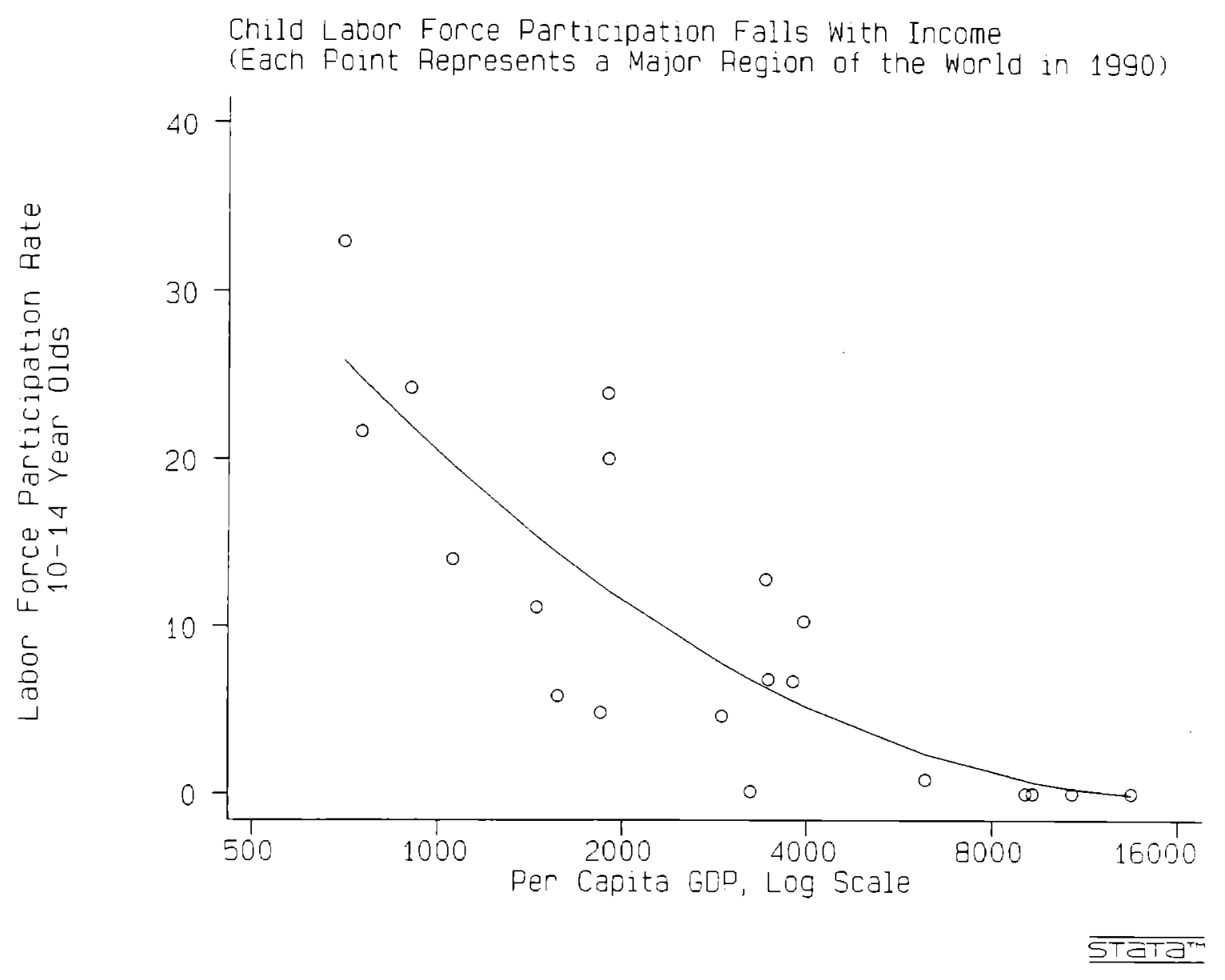

Figure 1 
Table 1

Determinants of Support for a Ban on Imports of Goods Produced with Child Labor

\begin{tabular}{|c|c|c|c|c|c|c|c|}
\hline \multirow[b]{2}{*}{ Variable } & \multirow[b]{2}{*}{$\begin{array}{l}\text { Mean } \\
{[\mathrm{SD}]}\end{array}$} & \multicolumn{3}{|c|}{ All } & \multicolumn{3}{|c|}{ Democrats } \\
\hline & & (1) & (2) & (3) & (4) & (5) & (6) \\
\hline $\begin{array}{l}\text { Proportion less } \\
\text { than high school }\end{array}$ & $\begin{array}{l}.25 \\
{[.09]}\end{array}$ & $\begin{array}{l}-.29^{*} \\
(.17)\end{array}$ & $\begin{array}{l}-.44^{*} \\
(.20)\end{array}$ & $\begin{array}{l}-.41^{*} \\
(.19)\end{array}$ & $\begin{array}{l}-.59^{*} \\
(.31)\end{array}$ & $\begin{array}{l}-.62^{*} \\
(.31)\end{array}$ & $\begin{array}{l}-.56^{*} \\
(.30)\end{array}$ \\
\hline Union Rate & $\begin{array}{c}.16 \\
{[.07]}\end{array}$ & $\begin{array}{l}.56^{*} \\
(.18)\end{array}$ & $\begin{array}{l}.49^{*} \\
(.23)\end{array}$ & $\begin{array}{l}.20 \\
(.22)\end{array}$ & $\begin{array}{l}1.02^{*} \\
(.40)\end{array}$ & $\begin{array}{l}.65 \\
(.44)\end{array}$ & $\begin{array}{l}.26 \\
(.45)\end{array}$ \\
\hline $\begin{array}{l}\text { For NAFTA and } \\
\text { GATT }\end{array}$ & $\begin{array}{l}.44 \\
{[.50]}\end{array}$ & -- & $\begin{array}{l}-.11^{*} \\
(.04)\end{array}$ & $\begin{array}{l}-.11^{*} \\
(.04)\end{array}$ & -- & $\begin{array}{l}-.16^{*} \\
(.06)\end{array}$ & $\begin{array}{l}-.16^{*} \\
(.06)\end{array}$ \\
\hline $\begin{array}{l}\text { For NAFTA, not } \\
\text { GATT }\end{array}$ & $\begin{array}{c}.09 \\
{[.29]}\end{array}$ & -- & $\begin{array}{l}-.08^{*} \\
(.03)\end{array}$ & $\begin{array}{l}-.07^{*} \\
(.03)\end{array}$ & -- & $\begin{array}{l}-.13^{*} \\
(.06)\end{array}$ & $\begin{array}{l}-.11^{*} \\
(.07)\end{array}$ \\
\hline $\begin{array}{l}\text { For GATT, not } \\
\text { NAFTA }\end{array}$ & $\begin{array}{c}.20 \\
{[.40]}\end{array}$ & - & $\begin{array}{l}-.02 \\
(.06)\end{array}$ & $\begin{array}{l}-.03 \\
(.06)\end{array}$ & -- & $\begin{array}{l}-.03 \\
(.07)\end{array}$ & $\begin{array}{l}-.03 \\
(.07)\end{array}$ \\
\hline ADA Rating & $\begin{array}{c}.45 \\
{[.36]}\end{array}$ & -- & -- & $\begin{array}{l}.31^{*} \\
(.07)\end{array}$ & -- & - & $\begin{array}{l}.35^{*} \\
(.09)\end{array}$ \\
\hline Democrat & $\begin{array}{l}.46 \\
{[.50]}\end{array}$ & $\begin{array}{l}.18^{*} \\
(.03)\end{array}$ & $\begin{array}{l}.17^{*} \\
(.03)\end{array}$ & $\begin{array}{l}-.03 \\
(.04)\end{array}$ & -- & -- & -- \\
\hline Vote in 1994 & $\begin{array}{l}.66 \\
{[.13]}\end{array}$ & $\begin{array}{l}.12 \\
(.10)\end{array}$ & $\begin{array}{l}.16 \\
(.13)\end{array}$ & $\begin{array}{l}.11 \\
(.12)\end{array}$ & $\begin{array}{l}.30 \\
(.27)\end{array}$ & $\begin{array}{l}.29 \\
(.27)\end{array}$ & $\begin{array}{l}.18 \\
(.26)\end{array}$ \\
\hline $\begin{array}{l}\text { Number of } \\
\text { Terms }\end{array}$ & $\begin{array}{c}4.84 \\
{[4.03]}\end{array}$ & $\begin{array}{l}.001 \\
(.004)\end{array}$ & $\begin{array}{c}.002 \\
(.004)\end{array}$ & $\begin{array}{l}.002 \\
(.004)\end{array}$ & $\begin{array}{l}.002 \\
(.006)\end{array}$ & $\begin{array}{l}.003 \\
(.006)\end{array}$ & $\begin{array}{c}.003 \\
(.006)\end{array}$ \\
\hline Sample Size & 434 & 434 & 345 & 345 & 188 & 188 & 188 \\
\hline
\end{tabular}

Notes: Mean of dependent variable is .08 in column $1, .09$ in columns 2 and 3 , and .17 in columns 4, 5 and 6. Data pertain to U.S. House of Representatives, 1995. Estimates are from a linear probability model. White standard errors are reported in parentheses. Source: Author's calculations.

* Statistically significant at 0.10 level. 
Table 2

Determinants of Support for NAFTA and GATT

Variable

(1)

(1)

NAFTA

(2)

$\frac{\text { GATT }}{(4)}$

$$
-.50
$$

Proportion less
than high school

$$
-.52 *
$$

$-.53 *$

(.31)

(.31)

Union Rate

-1.68 *

(.36)

$$
-1.64 \text { * }
$$

(.37)

.18

(.39)

.10

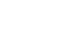

$-.05$

(.13)

- -

(.4I)

ADA Rating

Democrat

$-.37 \star$

-.34 *

(.10)

$-.04$

$(.06)$

.05

(.15)

$(.06)$

$-.05$

(.19)

$-.22$

(.21)

$-.09$

(.11)

Vote in 1994

(.19)

.004

$(.006)$

$-.001$

$-.26$

(.21)

Number of Terms

$(.006)$

345
$-.002$

$(.007)$
Sample size

345

347

Notes: 53 percent of the sample voted for NAFTA, and 63 percent voted for GATT. Coefficients are from a linear probability model. White standard errors are reported in parentheses.

Source: Author's calculations.

* Statistically significant at the 0.10 level. 


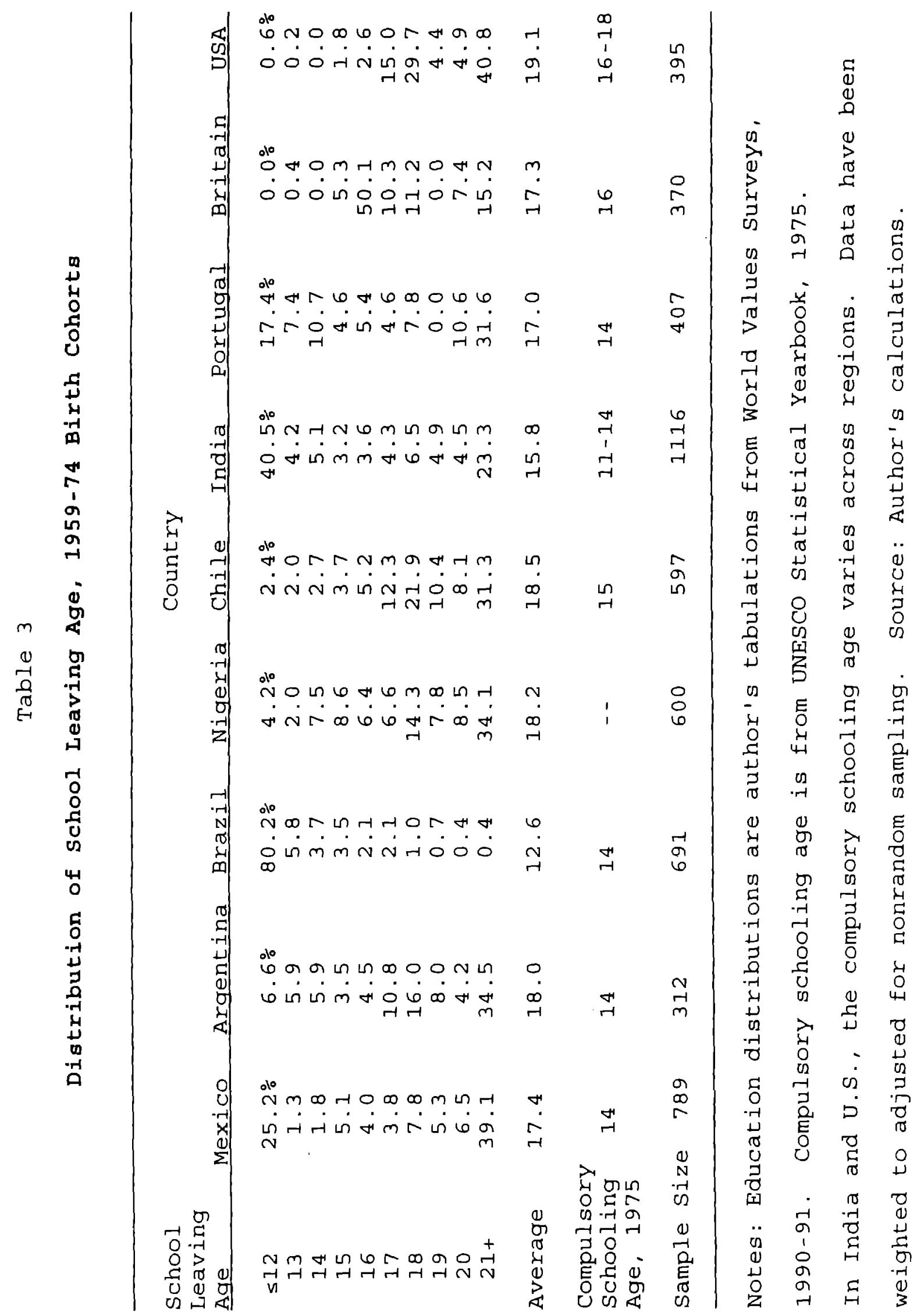


Table 4: School Leaving Age in Britain for Cohorts Affected by Varying Compulsory Schooling Laws

\begin{tabular}{|c|c|c|c|}
\hline \multirow{2}{*}{$\begin{array}{l}\text { School } \\
\text { Leaving } \\
\text { Age }\end{array}$} & \multicolumn{3}{|c|}{ Birth Cohort } \\
\hline & $<1932$ & $1933-56$ & $1958-74$ \\
\hline$\leq 12$ & 0.7 & 0.6 & 0.0 \\
\hline 13 & 3.4 & 0.7 & 0.4 \\
\hline 14 & 63.5 & 2.5 & 0.0 \\
\hline 15 & 5.1 & 40.4 & 5.4 \\
\hline 16 & 10.7 & 26.1 & 50.5 \\
\hline 17 & 4.8 & 9.7 & 10.5 \\
\hline 18 & 3.5 & 5.3 & 10.1 \\
\hline 20 & 1.9 & 1.7 & 8.0 \\
\hline $21+$ & 6.5 & 13.1 & 15.1 \\
\hline \multicolumn{4}{|l|}{ Compulsory } \\
\hline $\begin{array}{l}\text { Schooling } \\
\text { Age }\end{array}$ & 14 & 15 & 16 \\
\hline \multicolumn{4}{|l|}{ Sample } \\
\hline size & 450 & 574 & 400 \\
\hline
\end{tabular}

Source: Authors calculations from World

Values Surveys. Data have been weighted

to adjust for nonrandom sampling. 
Table 5: School Leaving Age in Brazil

for Cohorts Affected by Varying Compulsory Schooling Laws

\begin{tabular}{crc}
\hline \multirow{2}{*}{$\begin{array}{l}\text { School } \\
\text { Leaving } \\
\text { Age }\end{array}$} & \multicolumn{2}{c}{ Birth } \\
\cline { 2 - 3 } & $<1958$ & $>1962$ \\
s12 & 82.2 & 80.2 \\
13 & 2.7 & 5.8 \\
14 & 2.4 & 3.7 \\
15 & 3.3 & 3.5 \\
16 & 3.3 & 2.1 \\
17 & 1.9 & 2.1 \\
18 & 1.4 & 1.0 \\
19 & 0.6 & 0.7 \\
20 & 1.5 & 0.4 \\
$21+$ & 0.8 & 0.4 \\
Compulsory & & \\
Schooling & 11 & 14 \\
Age & & \\
Sample & & \\
size & 1091 & \\
\hline
\end{tabular}

Source: Authors calculations from world

Values Surveys. Data have been weighted to adjust for nonrandom sampling. 